\title{
Competitividad para la nodulación de rizobios aislados de Arachis glabrata
}

Fressoni, Melina S.; Collavino, Mónica M.

Instituto de Botánica del Nordeste, Facultad de Ciencias Agrarias (CONICET-UNNE)

*E-mail: mfressoni@hotmail.com

Introducción: Arachis glabrata Benth. es una leguminosa perenne de gran importancia como forrajera para los subtrópicos que crece naturalmente en el Nordeste Argentino (Corrientes y Misiones), en Paraguay Oriental y en los estados de Mato Grosso do Sul de Brasil. Las especies del género Arachis forman asociaciones simbióticas con bacterias fijadoras de $\mathrm{N}_{2}$ denominadas comúnmente rizobios. En $A$. glabrata se ha demostrado que la fijación simbiótica no proporciona el nitrógeno necesario para la producción óptima de esta especie indicando también la interacción con cepas indígenas inefectivas. En nuestro laboratorio hemos obtenido y caracterizado, mediante Rep-PCR y por secuenciación de los genes 16S ARNr, nodC y nifH, una colección de rizobios aislados a partir de nódulos de plantas de $A$. glabrata colectadas en las provincias de Corrientes y Misiones. Si bien se aislaron cepas de crecimiento rápido y lento, solo las especies de Bradyrhizobium fueron capaces de nodular eficientemente $A$. hypogaea y dentro del género solo los aislamientos del subcluster II 16S ARNr relacionados con especies nodulantes de soja, jicama y Aeschynomene americana fueron infectivas y efectivas con A. glabrata. A partir de estos resultados se propuso evaluar la capacidad de competencia de las cepas de la colección usando diferentes tipos de suelos no estériles.Esta caracterización de los aislamientos proveerá una base para la selección de rizobios que puedan ser utilizados en la formulación de un inoculante apropiado para el cultivo de A. glabrata en el NEA.

Materiales y métodos: Se ensayó la obtención de mutantes espontáneos resistentes a los siguientes antibióticos: espectinomicina, nalidixico, kanamicina, ampicilina, tetraciclina, cloranfenicol, rifampicina y estreptomicina. Solo se obtuvieron mutantes espontáneos de la cepa 4.4 resistentes a kanamicina. La estabilidad de la mutación se evaluó por sucesivos repiques en medio fresco y se confirmó la identidad de los clones por comparación de perfil REP-PCR con la cepa salvaje. Las plántulas de A. glabrata fueron obtenidas por regeneración in vitro. Las plantas regeneradas de aproximadamente $10 \mathrm{~cm}$ de porte aéreo fueron transplantadas a tres substratos diferentes: suelo arenoso, suelo rojo y un substrato orgánico.En cada tipo de substrato se ensayaron siete tratamientos: - Tratamiento control: plantas sin inocular Inoculaciones simples de las siguientes cepas: Bradyrhizobium sp. 9,1; Bradyrhizobium sp. 4,4; Bradyrhizobium Semia 6144 (cepa recomendada como inoculante de maní); 4,4 Km ${ }^{\mathrm{R}}$ - Co-inoculaciones (1:1) de la cepa mutante con 9,1 o con Semia 6144.Cada planta fue inoculada con $1 \mathrm{ml}$ de una suspensión de $1 \times 10^{6}$ células viables. Se realizaron diez repeticiones por cada tratamiento. Las plantas inoculadas fueron llevadas a invernáculo. A los 90 días de la inoculación, se evaluó: porcentaje de plantas noduladas, número total de nódulos por planta, peso seco aéreo y radicular, ocupancia del nódulo por comparación de los perfiles REP-PCR y resistencia a antibiótico (cepa 4.4).Se colectó un máximo de cuatro nódulos por planta, los nódulos desinfectados fueron plaqueados en medio YEM. En los tratamientos inoculados con la cepa resistente se plaqueó además en YEM suplementado con Kanamicina (100 mg/ml).

Resultados: En los tratamientos de inoculaciones simples con las cepas 4.4 o 9.1 se observaron plantas noduladas en todos los suelos ensayados, con valores mayores al $40 \%$ con 9.1 y de $100 \%$ con 4.4 . Por el contrario, en el tratamiento inoculado con la cepa SEMIA 6144 solo se observó nodulación en plantas crecidas en el suelo rojo (20\%) y con valores similares a lo observado en las plantas sin inocular (10\%). La inoculación con la cepa mutante $4.4 \mathrm{Km}^{\mathrm{R}}$ mostró un menor número de plantas noduladas (40\% a 60\%) a los observados con la cepa salvaje, lo que indicaría que la mutación afectó la capacidad infectiva. En la co-inoculación con $4,4 \mathrm{Km}^{\mathrm{R}}$ y Semia 6144 el porcentaje de plantas noduladas fue similar (30\% a $\left.60 \%\right)$ al observado con $4,4 \mathrm{Km}^{\mathrm{R}}$, por el contrario la co-inoculación con la cepa 9,1 presentó mayor número de plantas noduladas en todos los substratos $(60 \%$ a $100 \%)$. El promedio de nódulos por planta fue mayor en el substrato orgánico, observándose los mayores valores en los tratamientos inoculados con la cepa 4.4 y en la co-inoculación $4,4 \mathrm{Km}^{\mathrm{R}}$ y 9.1. Este último tratamiento mostró valores de peso seco aéreo significativamente mayores. Los valores de peso seco radicular no mostraron diferencias significativas entre tratamientos. Las cepas 4.4 y 91 fueron re-aisladas del 100\% de nódulos colectados de los tratamientos de inoculaciones simples en los tres suelos analizados. Se observó doble ocupancia en todos los nódulos recolectados, la cepa $4,4 \mathrm{Km}^{\mathrm{R}}$ mostró porcentajes similares, mayores al $50 \%$ en todos los casos,en la inoculación simple y en las co-inoculaciones.

Conclusiones: Podemos concluir que las cepas 4,4 y 9,1 son competitivas en la nodulación de plantas de Arachis glabrata en los diferentes substratos analizados. 